\section{Biosolid Residues as Soilless Media for Growing Creeping Bentgrass Sod}

\author{
Bruce R. Roberts, \\ Henry F. Decker, \\ Lindsey M. Ganahl, and \\ Elizabeth Yarmark
}

Additional index words. composted sewage sludge, flume sand, incinerated biosolids, recycling, Agrostis palustris, germination, dry mass accumulation, root:shoot ratio, rootzone mix

Summary. Two biosolid-containing waste media [composted sewage sludge (Com-Til) and incinerated biosolids (flume sand)] were evaluated as soilless media for growing 'Crenshaw', 'Penncross', and 'ProCup' creeping bentgrass sod (Agrostis palustris). The media were combined with sand and either sphagnum peat or a commercial growing mix (Metromix) and leached with $5.1 \mathrm{fl} \mathrm{oz}(150 \mathrm{~mL})$ tap water either zero, one or three times before seeding. Leaching with tap water to remove soluble salts had no beneficial effect on germination or dry mass accumulation. Flume sand was not a particularly good rootzone component for growing creeping bentgrass sod; however, a sieved [0.08-inch (2$\mathrm{mm})]$ medium consisting of sand, Com-Til and Metromix (8:1:1, by weight) seeded with 'ProCup' creeping bentgrass at $2 \mathrm{lb} / 1000 \mathrm{ft}^{2}$ $\left(9.8 \mathrm{~g} \cdot \mathrm{m}^{-2}\right)$ and grown over $4-\mathrm{mil}$ (0.004-inch, $0.10-\mathrm{mm})$ plastic in 3.5 $\times 7.5 \times 2$-inch deep $(9 \times 19 \times 5$-cm $)$ trays produced good sod in about 6 weeks.

Department of Botany and Microbiology, Ohio Wesleyan University, Delaware, $\mathrm{OH} 43015$.

We thank the City of Columbus, Ohio, for financially supporting this work and for providing the Com-Til and flume sand. We also wish to thank The Scotts Co. and Seed Technology, Inc., for providing the bentgrass seeds used in these investigations. The cost of publish ing this paper was defrayed in part by the payment of page charges. Under postal regulations, this paper therefore must be hereby marked advertisement solely to indicate this fact.
$\mathrm{L}$ arge acreage is devoted annually to the production and maintenance of sports turf (Tyler, 1996). This production is particularly true for golf course turf, since it has been estimated that, in the U.S. alone, there are more than 13,000 courses averaging 95 acres (38.4 ha) each (Steuteville, 1994). The use of composted waste products and recycled organic materials in golf course turf management has increased tremendously in recent years (Alexander and Tyler, 1992), especially for intensively managed areas such as golf greens and tees (Harlow, 1994). The reported benefits of using recycled waste products in golf course maintenance include: disease suppression, weed control, compaction relief and improved soil quality (Harlow, 1994; Tyler, 1996, Wilkinson, 1994).

Although conventional methods of grass sod production on soil require considerable time and expense, producing sod in a soilless growing medium spread over plastic can be accomplished more efficiently in much less time (Decker, 1989). Capitalizing on the tremendous capacity of grasses to quickly form a primary, fibrous root system, a high quality marketable sod can be produced in as little as 7 to 10 weeks. Not only is usable sod produced quicker by this technique than by conventional methods, but much less water, fertilizer, and mowing are required to produce it; the system conserves topsoil; valuable plant nutrients can be recovered and recycled; the resulting sod is often lighter in weight and easier to handle; and pesticide use is reduced or even eliminated (Decker, 1991). Unfortunately, this technology has not yet gained wide acceptance by a majority of sod producers or golf course superintendents.

In these experiments we investigated using two biosolid-containing residues (Com-Til and flume sand) in combination with other horticultural media and with or without plastic sheeting, to grow creeping bentgrass, the most widely used cool-season turfgrass on golf greens (Huang et al., 1998). These experiments were carried out in the greenhouse over a 2 -year period.

\section{Materials and methods}

Two biosolid-derived residues, both products of the solid waste facilities in Columbus, Ohio were used in these experiments: Com-Til (CT), a municipal sewage sludge composted with wood chips, and flume sand (FS), an ash by-product of incinerated municipal waste. Chemical analyses of these media are reported elsewhere (Roberts et al., 2001). Both residues were evaluated individually and together with sand (S) [Ogleby Norton Industrial Sands (Millwood Plant), Howard, Ohio] and either a commercial growing mix consisting of vermiculite, composted bark fines, peat moss, processed bark ash, and washed sand [Metromix 360 (MM); Scotts-Sierra Horticultural Products Co.,Marysville, Ohio], or Canadian sphagnum peat (P) (Conrad Fafard, Inc., Agawam, Mass.). The sand and peat used in these studies were consistent with U.S. Golf Association recommendations (USGA, 1993). Media consisting of two or more ingredients were always mixed by weight.

To check whether or not soluble salt content expressed as electrical conductivity (EC) and hydrogen ion concentration $(\mathrm{pH})$ of CT and $\mathrm{FS}$ might be toxic to creeping bentgrass, we first measured the $\mathrm{EC}$ and $\mathrm{pH}$ of leachate derived from each medium or combination of media. Samples [9.5 oz (269 g)] of each medium were placed in $3.25 \times$ $3.25 \times 3$-inch deep $(8.3 \times 8.3 \times 7.6 \mathrm{~cm})$ plastic pots and leached either zero, one or three times with $5.1 \mathrm{fl} \mathrm{oz}$ tap water before measuring $\mathrm{EC}$ and $\mathrm{pH}$ of the leachate.

Initially we evaluated the germination capacity of three creeping bentgrass cultivars (Crenshaw, Penncross, and ProCup) grown on combinations of unleached CT and FS alone and when mixed with S, MM, or P. 'Penncross' [a 1954 release used extensively in golf course construction (Decker and Decker, 1988)], 'Crenshaw' [a 1993 release showing good heat stress tolerance (Engelke et al., 1995)], and 'ProCup' [an advanced generation cultivar with high levels of resistance to the principal foliar diseases affecting creeping bentgrass (Plant Variety Protection Office, 1995)] were used in these trials.

In these experiments, 20 seeds each of each creeping bentgrass cultivar were planted in $3.25 \times 3.25 \times 3$-inch deep plastic pots containing CT and FS, either individually, together or combined with S, MM, or P. Although the quantity of seeds used in these studies was $<5 \%$ the recommended creeping bentgrass seeding rate of $2 \mathrm{lb} / 1000 \mathrm{ft}^{2}$, using fewer seeds allowed for more accurate determination of germination capacity. Seeded containers were trans- 
ferred to the greenhouse, and germination (expressed as percent of planted seeds that germinated) was recorded after 3 weeks.

Based on the results of these first experiments, further testing was continued using only one creeping bentgrass cultivar ('ProCup') and excluding media containing FS. In these and subsequent studies, the CT and P components used in each medium were screened through a 0.08 -inch sieve before mixing to ensure more uniform particle size. In this second set of experiments, $0.0007 \mathrm{oz}(20 \mathrm{mg})$ of 'ProCup' seeds (about 300 seeds) were planted in 1.3 inch $^{3}\left(2 \mathrm{~cm}^{3}\right)$ of media (CT mixed with $S$ and either MM or P) contained in the bottom-half of 2.4inch $(6.0-\mathrm{cm})$ diameter plastic petri dishes. Each dish had four 0.04-inch (1-mm) diameter holes spaced equidistantly in the base to facilitate drainage. The seeding rate used in these experiments was equivalent to the recommended seeding rate for creeping bentgrass $\left(2 \mathrm{lb} / 1000 \mathrm{ft}^{2}\right)$. To check the effect of pre-plant leaching treatments on seed germination and stand establishment, we used unleached media as well as media that had been leached with $5.1 \mathrm{fl} \mathrm{oz}$ of tap water either one or three times. Germination as well as shoot and root dry mass were recorded 6 weeks after planting. Dry mass data were obtained after ovendrying root and shoot tissue at $176^{\circ} \mathrm{F}$ $\left(80^{\circ} \mathrm{C}\right)$ for $48 \mathrm{~h}$. Root:shoot ratios were calculated from these data.

In the next set of experiments we studied the effect of a plastic liner on creeping bentgrass sod development. For these experiments, $0.006 \mathrm{oz} \mathrm{(170}$ $\mathrm{mg}$ ) of 'ProCup' seeds (equivalent to the recommended seeding rate) were planted in $3.5 \times 7.5 \times 2$-inch deep plastic trays (Mellinger's, North Lima, Ohio) containing 40 inch $^{3}\left(650 \mathrm{~cm}^{3}\right)$ of either $S, C T$ and $M M$ (8S:1CT:1MM) or $S$ and P (8S:2P). Half of the trays were fitted with 4 -mil plastic sheets containing 0.04 -inch diameter holes spaced at 2 -inch $(5-\mathrm{cm})$ intervals to facilitate drainage. Seeded trays, with or without plastic liners, were placed in the greenhouse. Shoot and root dry mass were measured after 6 weeks. Root:shoot ratios and root density were calculated from these data.

The experimental protocol used in these investigations was similar to that described elsewhere (Roberts et al., 2001) except that seeded containers were misted twice daily from above until plantings were established, after which they were watered from below every other day or as otherwise needed. Temperature and relative humidity conditions in the partially shaded greenhouse were 64 to $79^{\circ} \mathrm{F}\left(18\right.$ to $\left.26^{\circ} \mathrm{C}\right)$ and $65 \% \pm 15 \%$, respectively. Supplemental lighting was provided daily from 0600 to 1800 HR using 40-W coolwhite fluorescent lamps. Each experiment was conducted twice and the data combined to include both experiments. The experimental design was a randomized complete block with five or more replicates. Differences in treatment means were analyzed using the LSD method for pairwise comparisons (SAS Institute, Inc., 1988). To stan- dardize the variance, germination percentages were converted to arcsin transformations before statistical analyses.

\section{Results and discussion}

In media containing only CT or FS, leaching with tap water lowered $\mathrm{EC}$ and raised $\mathrm{pH}$ (Table $\mathrm{l}$ ). When $\mathrm{CT}$ and FS were mixed together, media with more CT (3CT:IFS) showed higher concentrations of soluble salts, whereas media with more FS (1CT:3FS) exhibited higher initial $\mathrm{pH}$ values. Changes in conductivity and $\mathrm{pH}$ observed after the leaching process could have been caused by the relatively high tap water $\mathrm{pH}$ or by the chemical nature of substrates from which these materials originated. In the case of CT specifically, these changes may have resulted from materials added to this biosolid during the composting process (Fitzpatrick et al., 1998).

Unwashed sand, the main component of most sports turf rootzone mixes and the primary ingredient in our soilless media, appeared to contribute only small quantities of soluble salts to the culture medium as suggested by the very low EC reading (Table 1). The same can be said for unleached P and MM both of which, by themselves, exhibited low conductivity $\left(0.33\right.$ and $0.50 \mathrm{dS} \cdot \mathrm{m}^{-1}$, respectively). Combining $S$ with $\mathrm{CT}$ (8S:2CT) increased conductivity appreciably relative to the $\mathrm{EC}$ reading recorded for $S$ by itself, although EC values for unleached media were still less than $3 \mathrm{dS} \cdot \mathrm{m}^{-1}$, the level at which

Table 1. Electrical conductivity (EC) and $\mathrm{pH}$ of unleached media (0) and leachate of the same media after flushing either once $(1 \times)$ or three times $(3 \times)$ with $5.1 \mathrm{fl} \mathrm{oz}(150 \mathrm{~mL})$ tap water. ${ }^{\mathrm{z}}$

\begin{tabular}{|c|c|c|c|c|c|c|}
\hline Com-Til (CT) & 2.98 & 2.03 & 1.56 & 5.30 & 7.41 & 7.64 \\
\hline 3CT:1FS & 3.16 & 2.90 & 1.26 & 5.41 & 7.45 & 7.41 \\
\hline 1CT:1FS & 2.42 & 2.63 & 0.97 & 5.63 & 7.28 & 7.25 \\
\hline $8 \mathrm{~S}: 2 \mathrm{CT}$ & 2.41 & 3.37 & 1.27 & 5.50 & 5.37 & 6.26 \\
\hline Peat $(\mathrm{P})$ & 0.33 & 0.48 & 0.52 & 3.49 & 3.53 & 3.64 \\
\hline $8 S: 2 \mathrm{P}$ & 0.40 & 0.57 & 0.54 & 3.60 & 3.94 & 3.98 \\
\hline 8S:1CT:1FS & 3.90 & 3.98 & 0.72 & 5.82 & 5.87 & 6.86 \\
\hline 8S:1CT:1P & 1.34 & 2.10 & 1.14 & 3.93 & 4.03 & 4.58 \\
\hline Metromix 360 (MM) & 0.50 & 0.94 & 0.85 & 5.80 & 7.06 & 6.82 \\
\hline
\end{tabular}

${ }^{\mathrm{z}}$ Each value is the average of duplicate samples. EC and $\mathrm{pH}$ of tap water $=0.40 \mathrm{dS} \cdot \mathrm{m}^{-1}$ and 8.58 , respectively.

yCombinations of two or more media mixed by weight. 
marginal necrosis has been observed in some plants (Rosen et al., 1993). Adding FS to a mixture of $S$ and CT (8S:1CT:1FS) increased EC above the $3 \mathrm{dS} \cdot \mathrm{m}^{-1}$ threshold, but replacing the FS component with either MM or P lowered conductivity below that threshold. For the various sand-based mixes used in our studies, a single leaching with tap water $(1 \times)$ caused effluent $E C$ to increase, but 3 leachings $(3 \times)$ resulted in an abrupt decrease in conductivity. Apparently the initial leaching process released ions that were only loosely adsorbed onto the particle surfaces comprising these media.

Media $\mathrm{pH}$, either too high or too low, can be a cause for concern in growing horticultural crops (Sanders et al., 1986). The $\mathrm{pH}$ of many biosolidcontaining composts used in golf course operations typically range from 6.5 to 8.0 (Wilkinson, 1994), and Alexander and Tyler (1992) suggest that compost products used as topdressing mixes in golf course maintenance should have a $\mathrm{pH}$ of 6.0 to 8.0. The $\mathrm{pH}$ of our unleached media, with the exception of media containing $\mathrm{P}$, ranged from 5.41 to 6.04 (Table 1). Although lower than the $\mathrm{pH}$ of many composted products currently used in golf course operations, we felt [based on earlier research (Roberts et al., 1995)] that the $\mathrm{pH}$ of unleached media would not negatively affect the growth of creeping bentgrass sod. Another consideration was the observation that media $\mathrm{pH}$ tended to increase slightly (about 5\% to 10\%) over the duration of these studies. A paper published by Cisar and Snyder (1992) reported an increase in $\mathrm{pH}$ of mixed urban waste compost, also used in growing sod, from 7.1 to 7.6 over a 6 week period.

The germination of creeping bentgrass 'Crenshaw' and 'Penncross' seeded on media composed only of CT or FS is shown in Table 2. After 3 weeks, germination of 'Crenshaw' ranged from $20 \%$ (on ICT:IFS) to $29 \%$ (on CT alone) while 'Penncross' ranged from $32 \%$ to $41 \%$ on the same two media. Germination of the same two cultivars on MM for a comparable period of time was $64 \%$ for 'Crenshaw' and $83 \%$ for 'Penncross'.

Since most golf course rootzone mixes are composed primarily of sand combined with organic components in the general ratio of 80:20 (USGA, 1993), we tested 'Crenshaw' and 'Penncross' germination on media con-

Table 2. Germination of three creeping bentgrass cultivars seeded on soilless media containing Com-Til (CT), flume sand (FS), sand (S), peat (P), or commercial growing mix (MM) and grown in the greenhouse for 3 weeks.

\begin{tabular}{|c|c|c|}
\hline Cultivar & Media composition & Germination $^{\mathrm{y}}(\%)$ \\
\hline \multirow[t]{8}{*}{ Crenshaw } & CT & $29 c$ \\
\hline & FS & $28 \mathrm{c}$ \\
\hline & 3CT:1FS & $24 \mathrm{~cd}$ \\
\hline & 1CT:1FS & $20 \mathrm{~d}$ \\
\hline & 1CT:3FS & $28 \mathrm{c}$ \\
\hline & MM & $64 a$ \\
\hline & $8 \mathrm{~S}: 2 \mathrm{CT}$ & $59 \mathrm{a}$ \\
\hline & 8S:1CT:1FS & $48 \mathrm{~b}$ \\
\hline \multirow[t]{9}{*}{ Penncross } & $\mathrm{CT}$ & $41 \mathrm{~d}$ \\
\hline & FS & $37 \mathrm{de}$ \\
\hline & 3CT:1FS & $34 \mathrm{e}$ \\
\hline & 1CT:1FS & $32 \mathrm{e}$ \\
\hline & 1CT:3FS & $34 \mathrm{e}$ \\
\hline & MM & $83 \mathrm{a}$ \\
\hline & $8 \mathrm{~S}: 2 \mathrm{CT}$ & $71 \mathrm{~b}$ \\
\hline & 8S:1CT:1FS & $60 \mathrm{c}$ \\
\hline & 8S:1CT:1MM & $77 \mathrm{a}$ \\
\hline \multirow[t]{4}{*}{ ProCup } & $8 S: 2 P$ & $80 \mathrm{~b}$ \\
\hline & 8S:1CT:1FS & $67 c$ \\
\hline & 8S:1CT:1MM & $89 \mathrm{a}$ \\
\hline & $8 S: 1 C T: 1 P$ & $90 \mathrm{a}$ \\
\hline
\end{tabular}

$\bar{z}$ Twenty seeds of each cultivar were planted in $3.25 \times 3.25 \times 2$-inch deep $(8.3 \times 8.3 \times 7.6$-cm $)$ plastic pots. Each value represents the mean of either five ('Crenshaw' and 'Penncross') or seven ('ProCup') replications. For each cultivar, means in a column followed by the same letter are not significantly different, $\operatorname{LSD}_{0.05}$.

yExpressed as percent of planted seeds that germinated. sisting of $8 \mathrm{~S}: 2 \mathrm{CT}$ and $8 \mathrm{~S}: 1 \mathrm{CT}: 1 \mathrm{FS}$. Three weeks after seeding, germination of both cultivars was significantly greater on media containing $S$ and $C T$ than on media containing $\mathrm{S}, \mathrm{CT}$, and FS (Table 2), suggesting that FS is probably less suitable than $\mathrm{CT}$ as a residue for growing creeping bentgrass sod. Part of the problem with FS may be its very fine particle size (33\% silt) which could have affected media oxygen content, water availability, or both during germination. Oxygen deficiencies are not uncommon in heavy finetextured soils or in layered soils with poor drainage (Huang et al., 1998). These trials also showed that 'Penncross' germination was consistently higher than 'Crenshaw' regardless of the media.

In another set of germination experiments, 'Penncross' testing was continued, and trials with another creeping bentgrass cultivar, 'ProCup', were initiated. In these studies 'Penncross' was seeded on media consisting of $S$ mixed with CT and MM (8S:1CT:1MM), and 'ProCup' was planted on three media mixes containing CT and one without CT. For 'Penncross', germination was greater (77\% versus $60 \%$ ) in media containing MM than in media with FS (Table 2). For 'ProCup', media containing either MM or P mixed with $S$ and CT (i.e., 8S:1CT:1MM or 8S:1CT:1P) showed greater capacity to support germination than the other media. As previously noted with 'Penncross' and 'Crenshaw', germination of 'ProCup' was poorest on media containing FS, further confirming our initial observation that FS was probably not a good component to include in rootzone mixtures seeded with creeping bentgrass. Overall, germination of 'ProCup' creeping bentgrass was consistently better than either of the other two creeping bentgrass cultivars grown on comparable media. Consequently, further testing was limited to 'ProCup' seeded on media composed of $S$ and CT mixed with either MM or P or a medium consisting of $S$ mixed with $P$.

We next investigated the effect of CT-containing media on germination and biomass production of 'ProCup' seeded at the recommended rate $(2$ $\mathrm{lb} / 1000 \mathrm{ft}^{2}$ ). These experiments were done in small plastic containers [2.4 inch diameter $\times 0.6$ inch deep $(6.0 \times$ $1.5 \mathrm{~cm})]$ in which media depth more closely approximated the shallow seed 
Table 3. Germination and growth of creeping bentgrass 'ProCup', seeded in leached and unleached media containing sand (S), peat (P), Com-Til (CT) and commercial growing mix (MM). ${ }^{\mathrm{Z}}$

\begin{tabular}{lccccc}
\hline Media & $\begin{array}{c}\text { Leaching } \\
\text { treatment }\end{array}$ & $\begin{array}{c}\text { Germination } \\
\left(\mathbf{m g}^{\mathbf{y}} \mathbf{c m}^{-2}\right)\end{array}$ & Shoot & Root & \multicolumn{2}{c}{$\begin{array}{c}\text { Root:shoot } \\
\text { ratio }\end{array}$} \\
\hline 8S:2P & 0 & $2.2 \mathrm{~d}$ & $47 \mathrm{~d}$ & $36 \mathrm{c}$ & $0.77 \mathrm{c}$ \\
& 1 & $1.9 \mathrm{de}$ & $39 \mathrm{de}$ & $40 \mathrm{c}$ & $1.03 \mathrm{~b}$ \\
8S:1CT:1MM & 3 & $1.4 \mathrm{e}$ & $29 \mathrm{e}$ & $32 \mathrm{c}$ & $1.10 \mathrm{~b}$ \\
& 0 & $5.7 \mathrm{~b}$ & $120 \mathrm{~b}$ & $217 \mathrm{a}$ & $1.81 \mathrm{a}$ \\
& 1 & $3.2 \mathrm{c}$ & $67 \mathrm{c}$ & $86 \mathrm{~b}$ & $1.28 \mathrm{~b}$ \\
8S:1CT:1P & 3 & $2.3 \mathrm{~d}$ & $49 \mathrm{~d}$ & $87 \mathrm{~b}$ & $1.78 \mathrm{a}$ \\
& 0 & $3.9 \mathrm{a}$ & $144 \mathrm{a}$ & $174 \mathrm{a}$ & $1.21 \mathrm{~b}$ \\
& 1 & $1.8 \mathrm{c}$ & $74 \mathrm{c}$ & $91 \mathrm{~b}$ & $1.23 \mathrm{~b}$ \\
& 3 & $38 \mathrm{de}$ & $47 \mathrm{c}$ & $1.24 \mathrm{~b}$
\end{tabular}

${ }^{\mathrm{z}}$ Seeds $[0.0007 \mathrm{oz}(20 \mathrm{mg})]$ were planted in 2.4 -inch $(6.0-\mathrm{cm})$ diameter plastic petri dishes. Each value represents the mean of seven replications. Means in a column followed by the same letter are not significantly different, $\mathrm{LSD}_{0.05}$.

yExpressed as shoot dry weight per unit area $\left(1.0 \mathrm{mg} \cdot \mathrm{cm}^{-2}=0.03 \mathrm{oz} / \mathrm{ft}^{2}\right)$.

bed conditions characteristic of many sod production systems grown over plastic (Cisar and Snyder, 1992; Decker, 1989). In these studies we measured root and shoot growth on media containing CT (8S:1CT:1MM and 8S:1CT:1P) and compared this with growth on a medium without $\mathrm{CT}$ (8S:2P). As part of this study we also measured the growth response of 'ProCup' seeded on leached and unleached media.

For creeping bentgrass seeded in unleached media, shoot and root mass after 6 weeks were always greater in soilless mixes containing CT than in the medium without CT (Table 3 ). Not only was dry mass accumulation significantly greater in CT-containing media, but the shoots of plants grown in these media appeared healthier and generally more vigorous. These observations suggest that $\mathrm{CT}$ may provide a source of nutrients not readily available in the non-CT medium. McCoy (1992) reported that various organic materials used in sand-based rootzone mixes can increase nutrient retention and maintain a stable supply of nutri- ents which plants can use between regular fertilizer applications.

Within the CT-containing media themselves, shoot mass was highest in the mixture containing $\mathrm{P}$, but root mass was greatest in the mixture containing MM. These data are reflected in the root:shoot ratio, which was 50\% higher for 'ProCup' growing in 8S:1CT:1MM than for 'ProCup' planted in 8S:1CT:1P. Since development of a primary fibrous root system is particularly important in sod establishment (Decker, 1989), the former medium seemed especially well suited for rapidly producing good quality sod.

Germination and growth of creeping bentgrass seeded on leached media (leached either one or three times with $5.1 \mathrm{fl} \mathrm{oz}$ tap water) was almost always less than that on unleached media (Table 3 ). This phenomenon was more pronounced for media containing $\mathrm{CT}$ (8S:1CT:1MM and 8S:1CT:1P) than for the medium without CT $(8 S: 2 \mathrm{P})$. These data led us to conclude that the time consuming process of leaching soilless media with tap water to control possible toxic accumulations of soluble salts was not necessary, at least for the media components used in our investigations. Apparently salt accumulation is not a serious problem in unleached media containing these particular ingredients, especially when only shallow layers of material are utilized.

In the final set of experiments, 'ProCup' creeping bentgrass was seeded on 40 inch $^{3}$ of either $8 \mathrm{~S}: 2 \mathrm{P}$ or $8 \mathrm{~S}: 1 \mathrm{CT}: 1 \mathrm{MM}$ in $3.5 \times 7.5 \times 2$-inch deep plastic trays with or without a 4mil polyethylene liner. Six weeks after planting, dry mass accumulation of roots and shoots was significantly greater in the medium containing CT than in the medium without CT regardless of the plastic liner (Table 4). For the medium containing CT, shoot growth was about the same (no significant difference) with or without plastic, but root growth was significantly greater in media planted over the plastic liner. These differences are also reflected in root density, which was $37 \%$ higher for plants grown in 8S:1CT:1MM over plastic than in the same medium without plastic.

Producing sod on soilless media

Table 4. Dry weight production of 'ProCup' creeping bentgrass seeded in soilless media containing sand (S), peat (P), Com-Til (CT), and commercial growing mix (MM) in plastic trays with and without plastic liners. ${ }^{z}$

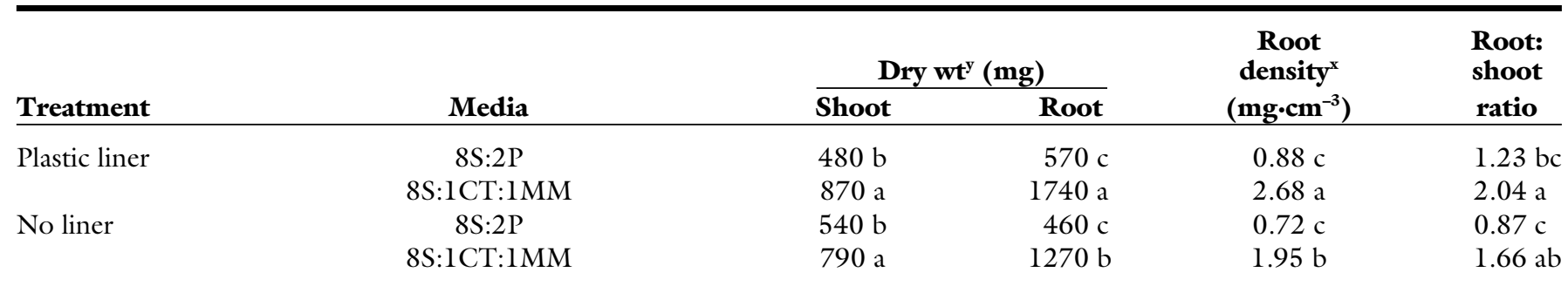

${ }^{z}$ Plastic trays $[3.25 \times 7.25 \times 2$-inch deep $(9 \times 19 \times 5-\mathrm{cm})]$ were planted with $0.006 \mathrm{oz}(170 \mathrm{mg})$ of seed. Each value represents the mean of seven replications. Means in a column followed by the same letter are not significantly different, $\mathrm{LSD}_{0.05}$

y $28,350 \mathrm{mg}=1.0 \mathrm{oz}$.

Expressed as root dry weight per unit volume $\left(1.0 \mathrm{mg} \cdot \mathrm{cm}^{-3}=1.0 \mathrm{oz} / \mathrm{ft}^{3}\right)$. 
spread over plastic has important advantages over conventional sod production. If conditions are maximized, rapidly growing root systems can quickly bind and knit a soilless medium into usable sod (Cisar and Snyder, 1992; Decker, 1975, 1989; Neel et al., 1978; Roberts et al., 1995). Our results suggest that creeping bentgrass root growth is particularly responsive to the growing conditions that exist when a plastic barrier is placed beneath a shallow layer of $S, C T$, and $M M$ $(8: 1: 1)$. Being unable to penetrate the impervious barrier (except occasionally at the location of 0.04 -inch diameter drainage holes), and bathed in a moist, well aerated medium, the fibrous root system developed very rapidly into a mature sod that was easily removed from the plastic surface. Used in conjunction with a mechanical planting system (Decker, 1998), it seems likely that a soilless medium like the one described in this paper could be employed successfully to grow creeping bentgrass sod more rapidly and efficiently.

We concluded from these greenhouse experiments that 'ProCup' creeping bentgrass seeded on a medium composed of sand (S), composted sewage sludge (CT), and a commercial growing mix (MM) in plastic trays at a ratio of $8 \mathrm{~S}: 1 \mathrm{CT}: 1 \mathrm{MM}, \mathrm{w} / \mathrm{w} / \mathrm{w}$ could be used to grow sod in about 6 weeks. Placing a 4-mil plastic liner in the base of each tray increased root mass and root:shoot ratio when compared to similar trays without plastic. Greenhouse trials using flume sand, a byproduct of incinerated sewage sludge, showed that this incinerated biosolid was not particularly well suited as a rootzone component for growing creeping bentgrass sod.

\section{Literature cited}

Alexander, R. and R.W. Tyler. 1992. Using compost successfully. Lawn and Landscape Maintenance 13:23-34.

Cisar, J.L. and G.H. Snyder. 1992. Sod production on solid-waste compost over plastic. HortScience 27:219-222.

Decker, H.F. 1975. Sewage sod system saves time. Weeds, Trees and Turf 14:4041 .

Decker, H.F. 1989. Growing sod over plastics: Turf in five weeks. Landscape Mgt. $28: 68,70$.

Decker, H.F. 1991. Compost use in sod production. Biocycle 32(3):64-65.

Decker, H.F. 1998. Liquid mulch apparatus for manufacturing sods. U.S. Patent $5,806,445$. U.S. Dept. Commerce, Patent and Trademark Office, Wash., D.C.

Decker, H.F. and J.M. Decker. 1988. Lawn care: A handbook for professionals. Prentice-Hall, Inc., Englewood Cliffs, N.J.

Engelke, M.C., V.G. Lehman, W.R. Kneebone, P.F. Colbaugh, J.A. Reinert, and W.E. Knoop. 1995. Registration of 'Crenshaw' creeping bentgrass. Crop Sci. 35:590.

Fitzpatrick, G.R., E.R. Duke, and K.A. Klock-Moore. 1998. Use of compost products for ornamental crop production: Research and grower experience. HortScience 33:941-944.

Harlow, S.J. 1994. The compost factor: It packs plenty of punch for turf. Turf North 7:20-21, 23.

Huang, B., L. Xiaozhong, and J.D. Fry. 1998. Shoot physiological responses of two bentgrass cultivars to high temperature and poor soil aeration. Crop Sci. 38:1219-1224.

McCoy, E.L. 1992. Quantitative physical assessment of organic materials used in sports turf rootzone mixes. Agron. J. 84:375-381.

Neel, P.L., E.O. Burt, P. Busey, and G.H. Snyder. 1978. Sod production in shallow beds of waste materials. J. Amer. Soc. Hort. Sci. 103:549-553.

Plant Variety Protection Office. 1995. Origin and breeding history of ProCup creeping bentgrass. PVP Cert. 9400257 . USDAARS, Beltsville, Md.

Roberts, B.R., S.D. Kohorst, H.F. Decker, and D. Yaussy. 1995. Shoot biomass of turfgrass cultivars grown on composted waste. Environ. Mgt. 19:735-739.

Roberts, B.R., H.F. Decker, K.J. Bagstad, and K.A. Peterson. 2001. Biosolid residues as soilless media for growing wildflower sod. HortTechnolgy 11:6-11.

Rosen, C.J., T.R. Halbach, and B.T. Swanson. 1993. Horticultural uses of municipal solid waste composts. HortTechnology 3:167-173.

Sanders, J.R., S.P. McGrath, and T. McM. Adams. 1986. Zinc, copper and nickel concentrations in ryegrass grown on sewage sludge-contaminated soils of different $\mathrm{pH}$. J. Sci. Food Agr. 37:961-968.

SAS Institute, Inc. 1988. SAS /STAT ${ }^{3}$ user's guide, 6.03 ed. p. 593-599. SAS Institute, Inc., Cary, N.C.

Steuteville, R. 1994. Golf course composting: Windrows on the links. Biocycle 35(6):30-33.

Tyler, R.W. 1996. Winning the organics game: The compost marketer's handbook. ASHS Press, Alexandria, Va.

U.S. Golf Association. 1993. USGA recommendations for a method of putting green construction. USGA Green Section Record. (March/April)1-3.

Wilkinson, J.F. 1994. Applying compost to the golf course. GolfCourse Mgt. 62:8088 . 